
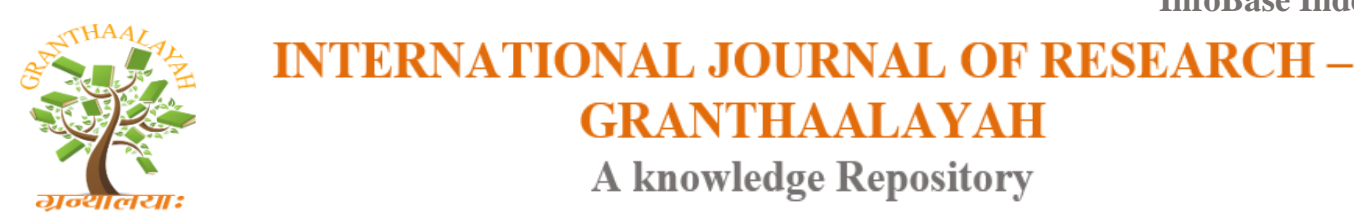

Science

\title{
ASSESSMENT OF WATER QUALITY OF BORE HOLE WATER IN TIRUCHENDUR
}

\author{
Esther Isabella Eucharista *1 \\ ${ }^{* 1}$ Assistant Professor in P.G Zoology, Aditanar College of Arts and Science, Tiruchendur, \\ TamilNadu, India
}

DOI: https://doi.org/10.29121/granthaalayah.v4.i12.2016.2400

\begin{abstract}
The present study was carried out on the assessment of water quality index (WQI) of bore hole water in Tiruchendur. All the analysis was done by APHA (2012) method. Here the result pointed out that $\mathrm{pH}$ was recorded maximum as $7.16 \pm 0.03$ during July and September 2016. TDS concentration was obtained high as $2400 \pm 2.000 \mathrm{mg} / \mathrm{l}$ during September 2016. TA content was noticed high as $688 \pm 2.51 \mathrm{mg} / \mathrm{l}$ during September 2016. TH range was high as $800 \pm 2.00 \mathrm{mg} / \mathrm{l}$ during August 2016. The concentration of Ca was recorded high as $200 \pm 1.53 \mathrm{mg} / \mathrm{l}$ during August and September. All the parameters were exceeded the permissible limit of WHO except $\mathrm{pH} . \mathrm{pH}$ had a positive relationship with TDS and TA and had a negative relationship with TH and Ca. TDS had a positive correlation with TA, TH and Ca. TA had a positive relationship with TH and $\mathrm{CA}$. TH had a highly significant positive correlation with $\mathrm{Ca}$. The bore hole water was not so good when compared with other South Indian bore hole water. The water quality index indicated that the water was highly polluted by the domestic effluents and sewage waste water. It was unfit for human consumption without treatment.
\end{abstract}

Keywords: WQI; Permissible Limit; Polluted.

Cite This Article: Esther Isabella Eucharista. (2016). "ASSESSMENT OF WATER QUALITY OF BORE HOLE WATER IN TIRUCHENDUR.” International Journal of Research - Granthaalayah, 4(12), 124-131. https://doi.org/10.29121/granthaalayah.v4.i12.2016.2400.

\section{Introduction}

The health of our water is the principal measure of how we live on the land. Ground water is one of the most valuable natural resource which supports human health, agriculture, economic development and ecological diversity.

Water has always been an essential and life sustaining drinks to humans and is significant for the survival of all known organisms [5]. According to Central pollution board, $90 \%$ of the water supplied in India to the town and cities are polluted out of which only $1.6 \%$ gets treated. 
Therefore water quality management is necessary for the human welfare [10]. The necessity of water in the day to day life in man included for cooking, washing, drinking purpose [1] .

$96.5 \%$ of the planet water is found in seas and oceans $1.7 \%$ in ground water $1.7 \%$ in glacier's and the ice caps of Antarctica and Greenland a small fraction in other large water bodies and $0.001 \%$ in the air as vapour clouds and precipitation earth's approximate water volume is $1338,000 \mathrm{~km}^{3}$ only $2.5 \%$ of the earth's water is fresh water and $98.8 \%$ of the water is in ice and ground water less than $0.3 \%$ of all fresh water is in rivers, lakes and the atmosphere and an even small amount of the earth's fresh water $(0.003 \%)$ is contained within biological bodies and manufactured products approximately $70 \%$ the fresh water used by humans goes to agriculture.

Sanitation and hygiene-related causes nearly death, 99\% occur in the developing world [11]. Ground water quality comprises the physical, chemical and biological characteristics of ground water. It acts as the indicators of the water quality [9]. WQI provides a single number that express overall water quality at a certain location and time based on several water quality parameters[12].

WQI a well - known method as well as one of the most effective tools to express water quality that offers a simple, stable, reproducible unit of measure and communicable to the policy makers and concerned citizens. The present study deals with the ground water quality index Tiruchendur as it depends upon on the washing and agricultural purposes by the surrounding area people.

Our present study has been undertaken, the following objectives such as

- To assess the physic-chemical parameters of the bore hole water at Tiruchendur.

- To evaluate the standard deviation.

- Comparing the values obtained from analysis with that of WHO guidelines with a view to improve the quality of bore hole water.

- To assess Pearson correlation matrix of the ground water.

- To determine the water quality index of bore hole water at Tiruchendur.

\section{Study Area}

The water sample was collected randomly from the bore hole in Tiruchendur town. It was situated in a house which is owned by Mr. N.Thinakaran. The house was located in Mutharamman Kovil Street at Tiruchendur (Figure 1). The bore hole sited in the house was about $2 \mathrm{~km}$ away from the Bhathsingh bus stand at Tiruchendur. The depth is about 20 inches and the length is $4 \mathrm{~cm}$. The house lies within longitude $7^{0} 8^{\prime} \mathrm{E}$ and latitude $8^{0} 49^{\prime} \mathrm{N}$. 


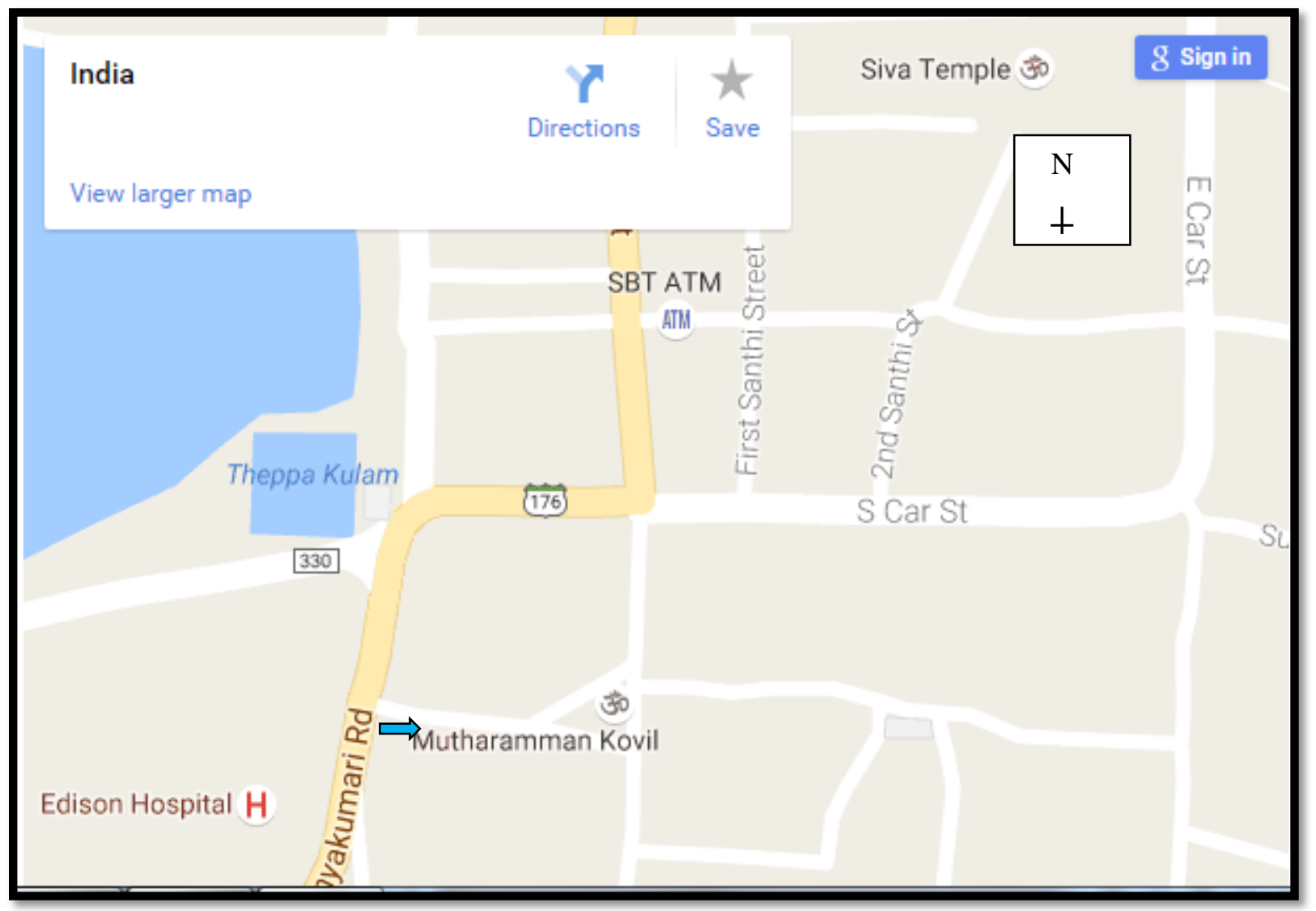

Figure 1: Location of the Study Area Google Map Satellite

\section{Sample Collection}

The samples were collected from July 2016 to September 2016 from the bore hole at Tiruchendur. The samples were collected in $2 \mathrm{~L}$ plastic container which had been thoroughly washed and filled with distilled water the taken to the sampling site. The bottle was emptied and rinsed several times with the water to be collected. Also the sample bottle was partially filled with the collected water and vigorously shaken. The sample bottle was tightly covered immediately after collection. It was then kept in waters containing ice blocks and transported to the laboratory for preservation in a refrigerator before analysis was carried out on them. These were analyzed as per the procedures given in the standard method [2].

\section{Statistical Analysis}

Statistical analysis was conducted using the Microsoft Excel Version 2010. The Pearson correlation analysis was carried out to determine significant relationship between parameters/ variables in hydrology and water quality.

\section{Water Quality Index}

The weighed arithmetic index method has been used for the calculation of WQI of the water body. Further, quality rating or sub index $\left(\mathrm{q}_{\mathrm{n}}\right)$ was calculated using the following expression. 
$\mathrm{q}_{\mathrm{n}}=100\left[\mathrm{~V}_{\mathrm{n}}-\mathrm{V}_{\text {io }}\right] /\left[\mathrm{S}_{\mathrm{n}}-\mathrm{V}_{\text {io }}\right]$

$\mathrm{q}_{\mathrm{n}}=$ Quality rating for the $\mathrm{n}^{\text {th }}$ water quality parameter

$\mathrm{V}_{\mathrm{n}}=$ Estimated value of the $\mathrm{n}^{\text {th }}$ parameter at a given sampling

$\mathrm{S}_{\mathrm{n}}=$ Standard permissible value of the $\mathrm{n}^{\text {th }}$ parameter

$\mathrm{V}_{\mathrm{io}}=$ Ideal value of $\mathrm{n}^{\text {th }}$ parameter in water (i.e. $O$ for all other parameter except the parameter $\mathrm{pH}$ and Dissolved Oxygen (7.0 and $14.6 \mathrm{mg} / \mathrm{l}$ respectively)

Unit weight was calculated by a value inversely proportional to the recommended standard value $\mathrm{S}_{\mathrm{n}}$ of the corresponding parameter.

$\mathrm{W}_{\mathrm{n}}=\mathrm{K} / \mathrm{S}_{\mathrm{n}}$

$\mathrm{W}_{\mathrm{n}}=$ Unit weight for the $\mathrm{n}^{\text {th }}$ parameter

$\mathrm{S}_{\mathrm{n}}=$ Standard value for $\mathrm{n}^{\text {th }}$ parameter

$\mathrm{K}=$ Constant for proportionality.

The overall water quality index was calculated by aggregating the quality rating with the unit weight linearly.

$\mathrm{WQI}=\Sigma \mathrm{q}_{\mathrm{n}} \mathrm{W}_{\mathrm{n}} / \Sigma \mathrm{W}_{\mathrm{n}}$

\section{Results and Discussion}

$p H$

$\mathrm{pH}$ of water sample varied from $7.1 \pm 0.2$ to $7.16 \pm 0.03$. The highest mean concentration was noticed as 7.16 \pm 0.03 during July and September 2016. This may be due to encrusted pipelines. The bore hole water samples however indicated positive correlation between $\mathrm{pH}$ and TDS $(\mathrm{r}=0.021), \mathrm{pH}$ and TA $(\mathrm{r}=0.500)$ while negative correlation was observed $\mathrm{pH}$ and $\mathrm{TH}(\mathrm{r}=-0.693)$, $\mathrm{pH}$ and $\mathrm{Ca}(\mathrm{r}=-0.500)$.It can be seen that the concentrations of the respective parameter $\mathrm{pH}$ was below the WHO standards as shown in table 1 . This may be due to water pipelines encrustations and appliances [6].

Table 1: Rating Scale of Physico-Chemical Parameters of Water (Who Standards)

\begin{tabular}{|l|l|l|}
\hline S.No & Parameters (Units) & Standards \\
\hline 1. & $\mathrm{P}^{\mathrm{H}}$ & $6.5-8.0$ \\
\hline 2. & Total dissolved solids $(\mathrm{mg} / \mathrm{l})$ & $500 \mathrm{mg} / \mathrm{l}$ \\
\hline 3. & Total Alkalinity $(\mathrm{mg} / \mathrm{l})$ & $120 \mathrm{mg} / \mathrm{l}$ \\
\hline 4. & Total Hardness $(\mathrm{mg} / \mathrm{l})$ & $300 \mathrm{mg} / \mathrm{l}$ \\
\hline 5. & Calcium $(\mathrm{mg} / \mathrm{l})$ & $75 \mathrm{mg} / \mathrm{l}$ \\
\hline
\end{tabular}

\section{Total Dissolved Solids}

The maximum concentration of total dissolved solids was obtained as $2400 \pm 2.000 \mathrm{mg} / \mathrm{l} \mathrm{during}$ September 2016. The TDS was positively correlated with TA $(r=0.876), \mathrm{TH}(\mathrm{r}=0.705)$ and $\mathrm{Ca}$ $(\mathrm{r}=0.855)$.The TDS was exceeded the permissible limit of WHO standard. High concentration may be due to bathing and laundering these may affect persons those who suffering from kidney and heart diseases. Water containing high concentration solids may also cause the effect of laxative and constipation [8]. 


\section{Total Alkalinity}

The TA content was high during September recorded as $688 \pm 2.51 \mathrm{mg} / \mathrm{l}$. The TA was positively correlated with $\mathrm{TH}(\mathrm{r}=0.277)$ and $\mathrm{Ca}(\mathrm{r}=0.500)$ (Table 2). The highest concentration of TA was higher than the WHO recommended limit. The excessive alkalinity may be due to encrusted pipes and utensils which may cause stomach upset.

Table 2: Pearson Correlation Matrix of Water Quality Parameter

\begin{tabular}{|l|l|l|l|l|l|}
\hline Parameters & pH & TDS & TA & TH & Ca \\
\hline pH & 1 & & & & \\
\hline TDS & 0.021 & 1 & & & \\
\hline TA & 0.500 & 0.876 & 1 & & \\
\hline TH & -0.693 & 0.705 & 0.277 & 1 & \\
\hline Ca & -0.500 & 0.855 & 0.500 & $0.970^{* *}$ & 1 \\
\hline
\end{tabular}

*Correlation is significant at the 0.05 level ( 2 - Tailed)

** Correlation is highly significant at the 0.01 level $(2$ - Tailed)

\section{Total Hardness}

TH range was observed high during August as $800 \pm 2.00 \mathrm{mg} / \mathrm{l}$ (Figure 1). Positive relationship was observed between $\mathrm{TH}$ and $\mathrm{Ca}(\mathrm{r}=0.970)$. TH was exceeded than the WHO permissible limit. The high level of hardness may be usages of soap during bathing. It may also lead by deposition of soap in pipes.

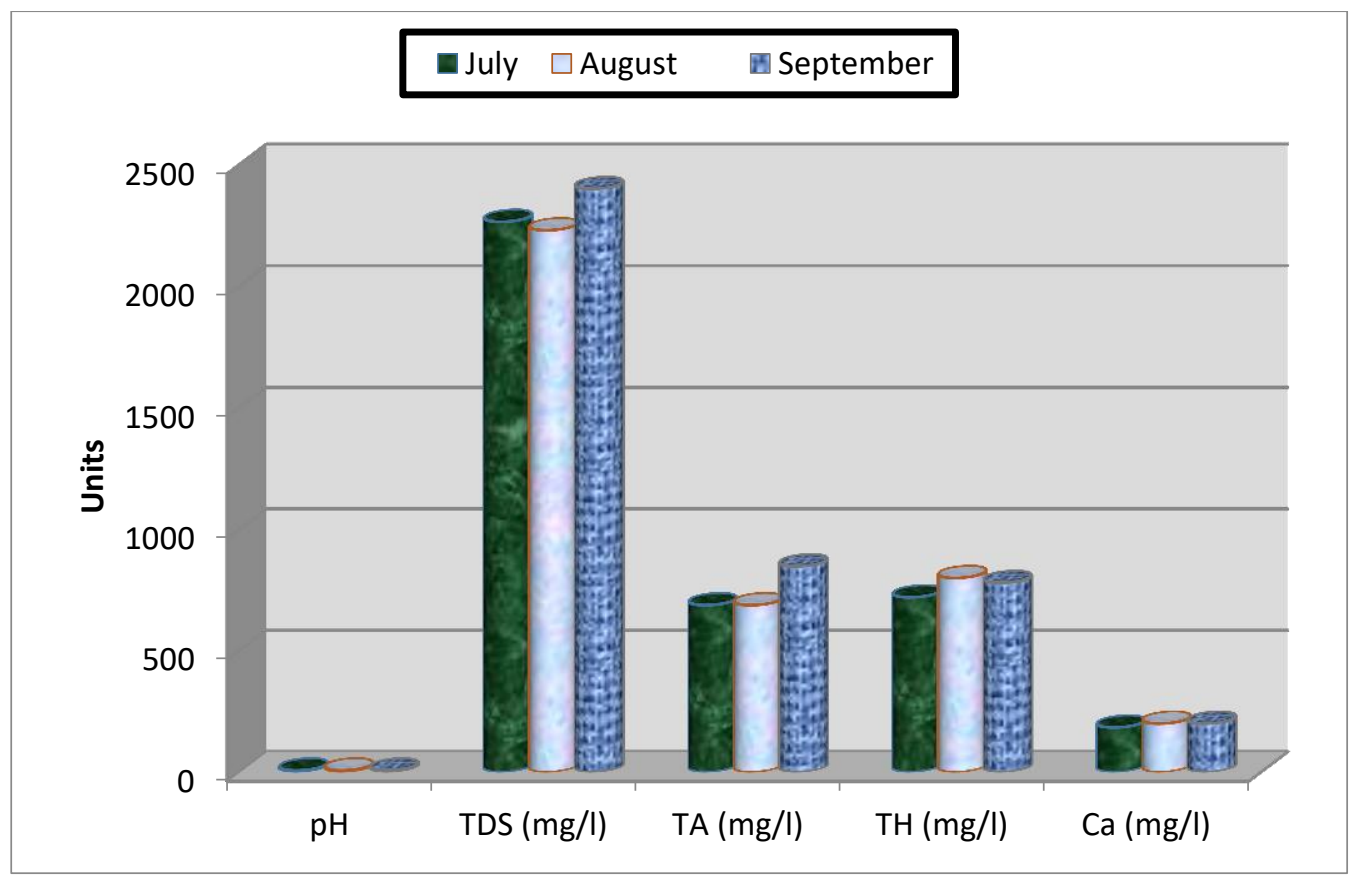

Figure 1: Monthly Variations in Water Quality Index of Bore Hole Water From July to September 2016 


\section{Calcium}

The Maximum concentration of $\mathrm{Ca}$ was observed during August and September 2016 as $200 \pm 1.53 \mathrm{mg} / \mathrm{l}$. The highest concentration was exceeded than the permissible limit of WHO. Calcium was negatively correlated with $\mathrm{pH}$ and positively related with TDS and TA but it showed highly significant positive correlation with TH. Excess Ca contributes to the hardness of water from bathing, laundering and washing. This may also cause problems such as formation of stones in the kidney. It may also affect the metabolic processes in the body. Available literatures were also in close conformity with [3, 4 \&7].

Table 3: Water Quality Index (Wqi) and Status of Water Quality

\begin{tabular}{|l|l|}
\hline Water Quality Index Level & Water Quality Status \\
\hline $0-25$ & Excellent water quality \\
\hline $26-50$ & Good water quality \\
\hline $51-75$ & Poor water quality \\
\hline $76-100$ & Very poor water quality \\
\hline$>100$ & Unsuitable for drinking \\
\hline
\end{tabular}

\section{Water Quality Index}

Water quality index of the present study was established from the physic-chemical parameters in July, August and September were 76.06, 75.66 and 86.5 respectively. The value was represented in Figure 2. The water quality status indicated that it was very poor (Table 3) when compared with other South Indian bore hole waters.

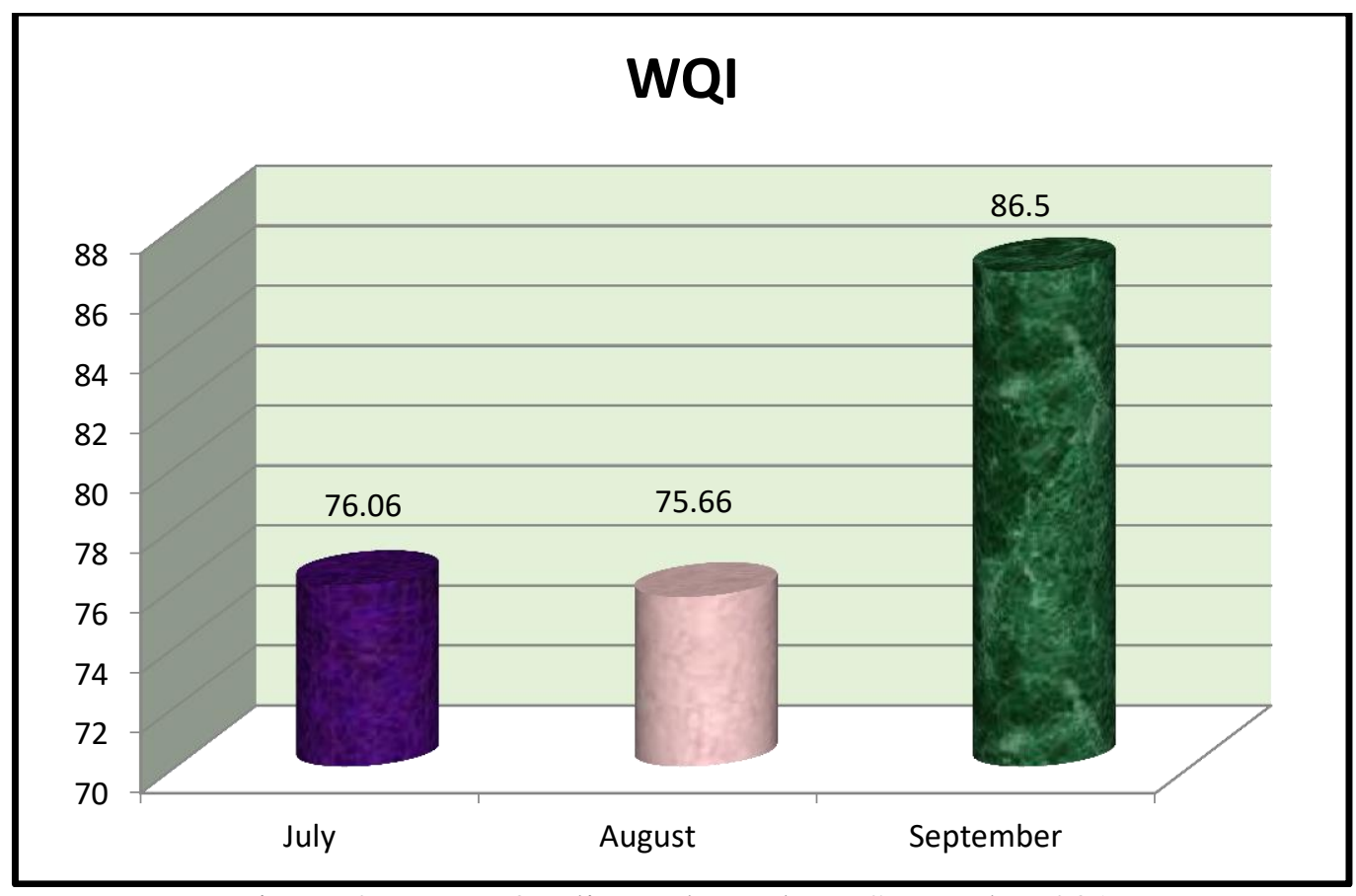

Figure 2: Water Quality Index July to September 2016 


\section{Recommendations}

- Rainwater harvesting must be provided and should be made compulsory for each residential unit as it is considered as the economical solution.

- Consideration of schemes to construct artificial recharge structures.

- Provision of government owned treatment units like reverse osmosis, desalination ionexchange process etc. To prevent the consumption of marginal quality water.

- A ground water assessment and estimation study should be conducted each year for better understanding of groundwater quality variation.

- Proper and appropriate treatment should be done according to seasonal variation with respect to important physic-chemical parameters.

- Proper sanitation should be strictly observed around the vicinity of the boreholes.

- To create public awareness about non-biodegradable materials like plastic covers, bottles, metal glass pieces, garbage etc., are thrown into soil.

- To educate the human dwellings around the soil about the domestic wastes.

- Public awareness programs need to be developed for sustainable management of groundwater.

\section{Conclusion}

The status of ground water quality in the study area is found to be critical. The presence of high TDS, TH, TA and Ca occurs in most of the months. The source of these contaminants is attributed to anthropogenic sources such as sewage effluents, household solid wastes and waste water. Even though treatments like reverse osmosis, distillation, activated carbon etc., can eliminate the prevailing contamination the present scenario needs consideration on rain water harvesting, waste water reuse and water treatment techniques. The study revealed that the water quality was unfit for human consumption without treatment. Controlled waste disposal practice should be encouraged to minimize groundwater contamination.

\section{References}

[1] Akpoborie, T, Egbo, S.H.O, Ebenuwa, C.C and Emeshili, E.M .Comparative study of the satchet water in Asaba Metropolis, South-South, Nigeria. 4, 2008, 29-33.

[2] APHA. Standard methods for the Examination of water and waste water.22nd Ed. American Public Health Association(APHA), American Water Works Association (AWWA) \& Water Environment Federation (WEF), Washington D.C., U.S.A.2012.

[3] Aremu, M.O, Sangari, D.U, Musa, B.Z and Chaanda, M.S. Assessment of groundwater and stream for trace metals and physic-chemical contaminations of Toto Local Government area of Nassarawa state, Nigeria.3,2008, 12-20

[4] Fleck, H . Introduction to natrition, 3rd edn. Macmillian, New York, U.S.A.1976.

[5] Greenhalgh, Alison (2001)." Healthy living - Water". BBC Health. Retrived 2007: 02-19.

[6] Gupta, D.P, Sunita and Saharan, J.P. Physico-chemical analysis of groundwater of selected area of Kaithal city (Haryana) India, Researcher, 1(2), 2009, pp 1-5.

[7] Igwemmar, N.C, Kolawole, S.A and Okunoye, L.K. Physical and chemical assessment of some selected borehole water in Gwagwalada, Abuja, International Journal of Scientific \& Technology Research Vol 2(11), 2013, 67-75.

[8] Kumaraswamy, N.J. Pollut Res., 1999. 
[9] Packialakshmi, S. Meheli Deb and Hrituparna Chakraborty. Assessment of groundwater quality index in and around Sholinganallur area, TamilNadu. Indian Journal of Science and Technology. 8(6), 2015, 10-17.

[10] Rajdeepkaur and Singh, R.V.. Correlation analysis of groundwater quality of Bichhwal Industrial area Bzikaner. International Journal of Chemical, Environmental and Pharmaceutical research. Vol-2, 2011, pp-146-151.

[11] World Health Organization (WHO). (2008). Safer water, better health: Costs, benefitsand sustainability of interventions to protect and promote health; Updated Table 1: WSH deaths by region, 2004.

[12] Yogendra, K and Puttaiah, E.T. Determination of water quality index and suitability of an urban waterbody in Shimoga Town, Karnataka. The 12th World Lake conference. 28, 2008, 342-346.

*Corresponding author.

E-mail address: estherisabella78@gmail.com 